\title{
THE
}

\section{Effect of Vinylene Carbonate and Fluoroethylene Carbonate on SEI Formation on Graphitic Anodes in Li-lon Batteries}

\author{
Mengyun Nie \\ University of Rhode Island \\ Julien Demeaux \\ University of Rhode Island \\ Benjamin T. Young \\ University of Rhode Island \\ David R. Heskett \\ University of Rhode Island, dheskett@uri.edu \\ Yanjing Chen \\ University of Rhode Island \\ Sertow thpage for addditionalalathor:Shttps://digitalcommons.uri.edu/chm_facpubs \\ Creative Commons License \\ (c) (i)
}

This work is licensed under a Creative Commons Attribution 4.0 License.

\section{Citation/Publisher Attribution}

Nie, M., Demeaux, J., Young, B. T., Heskett, D. R., Chen, Y., Bose, A., Woicik, J. C., \& Lucht, B. L. (2015).

Effect of Vinylene Carbonate and Fluoroethylene Carbonate on SEl Formation on Graphitic Anodes in LiIon Batteries. J. Electrochem. Soc., 162(13), A7008-A7014. doi: 10.1149/2.0021513jes

Available at: http://dx.doi.org/10.1149/2.0021513jes

This Article is brought to you for free and open access by the Chemistry at DigitalCommons@URI. It has been accepted for inclusion in Chemistry Faculty Publications by an authorized administrator of DigitalCommons@URI. For more information, please contact digitalcommons-group@uri.edu. 


\section{Authors}

Mengyun Nie, Julien Demeaux, Benjamin T. Young, David R. Heskett, Yanjing Chen, Arijit Bose, Joseph C. Woicik, and Brett L. Lucht 


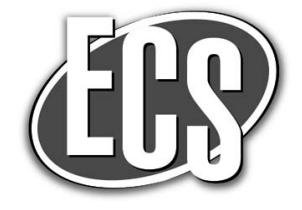

JES Focus Issue on Electrochemical Interfaces in Energy Storage Systems

\title{
Effect of Vinylene Carbonate and Fluoroethylene Carbonate on SEI Formation on Graphitic Anodes in Li-Ion Batteries
}

\author{
Mengyun Nie, ${ }^{\text {a Julien Demeaux }}{ }^{\text {a }}$ Benjamin T. Young, ${ }^{b}$ David R. Heskett, ${ }^{b}$ Yanjing Chen, \\ Arijit Bose, ${ }^{\mathrm{c}}$ Joseph C. Woicik, ${ }^{\mathrm{d}}$ and Brett L. Lucht ${ }^{\mathrm{a}, *, \mathrm{z}}$ \\ ${ }^{a}$ Department of Chemistry, University of Rhode Island, Kingston, Rhode Island 02881, USA \\ ${ }^{b}$ Department of Physics, University of Rhode Island, Kingston, Rhode Island 02881, USA \\ ${ }^{c}$ Department of Chemical Engineering, University of Rhode Island, Kingston, Rhode Island 02881, USA \\ ${ }^{d}$ National Institute of Standards and Technology, Gaithersburg, Maryland 20899, USA
}

\begin{abstract}
Binder free (BF) graphite electrodes were utilized to investigate the effect of electrolyte additives fluoroethylene carbonate (FEC) and vinylene carbonate (VC) on the structure of the solid electrolyte interface (SEI). The structure of the SEI has been investigated via ex-situ surface analysis including X-ray Photoelectron spectroscopy (XPS), Hard XPS (HAXPES), Infrared spectroscopy (IR) and transmission electron microscopy (TEM). The components of the SEI have been further investigated via nuclear magnetic resonance (NMR) spectroscopy of $\mathrm{D}_{2} \mathrm{O}$ extractions. The SEI generated on the BF-graphite anode with a standard electrolyte (1.2 $\mathrm{M} \mathrm{LiPF}_{6}$ in ethylene carbonate (EC) / ethyl methyl carbonate (EMC), 3/7 (v/v)) is composed primarily of lithium alkyl carbonates (LAC) and $\mathrm{LiF}$. Incorporation of $\mathrm{VC}(3 \% \mathrm{wt})$ results in the generation of a thinner SEI composed of $\mathrm{Li}_{2} \mathrm{CO}_{3}, \operatorname{poly}(\mathrm{VC})$, $\mathrm{LAC}$, and $\mathrm{LiF}$. Incorporation of $\mathrm{VC}$ inhibits the generation of $\mathrm{LAC}$ and $\mathrm{LiF}$. Incorporation of $\mathrm{FEC} \mathrm{(3 \%} \mathrm{wt)} \mathrm{also} \mathrm{results} \mathrm{in} \mathrm{the}$ generation of a thinner SEI composed of $\mathrm{Li}_{2} \mathrm{CO}_{3}$, poly(FEC), LAC, and LiF. The concentration of poly(FEC) is lower than the concentration of poly $(\mathrm{VC})$ and the generation of LAC is inhibited in the presence of FEC. The SEI appears to be a homogeneous film for all electrolytes investigated.

(c) The Author(s) 2015. Published by ECS. This is an open access article distributed under the terms of the Creative Commons Attribution 4.0 License (CC BY, http://creativecommons.org/licenses/by/4.0/), which permits unrestricted reuse of the work in any medium, provided the original work is properly cited. [DOI: 10.1149/2.0021513jes] All rights reserved.
\end{abstract}

Manuscript submitted June 11, 2015; revised manuscript received July 10, 2015. Published July 23, 2015. This paper is part of the JES Focus Issue on Electrochemical Interfaces in Energy Storage Systems.

Lithium ion batteries have been used to power portable electronic devices for decades. Interest in lithium ion batteries has expanded to include electric vehicles (EV) due to their high energy density. ${ }^{1-3}$ However, the calendar life of many lithium ion batteries is insufficient for the $>10$ year life expectancy of an EV. ${ }^{1}$ Thus there have been many recent investigations on methods to improve the calendar life of lithium ion batteries. Graphite is the most widely used anode material in lithium ion batteries. ${ }^{4,5}$ During the initial charging cycles of the lithium ion battery a Solid Electrolyte Interphase (SEI) is generated on the graphite surface. ${ }^{6,7}$ The SEI acts as a passivation layer to inhibit further electrolyte reduction. ${ }^{8}$ The SEI generated from standard ethylene carbonate based electrolytes has moderate thermal stability which leads to moderate calendar life. ${ }^{9}$ In an effort to improve the stability of the SEI many film forming additives have been investigated. ${ }^{10,11}$ Vinylene Carbonate (VC) and Fluoroethylene Carbonate (FEC) are among the most widely investigated electrolyte additives. ${ }^{12}$ VC has been used in many lithium ion batteries to increase first cycle efficiency, improve the high temperature stability, and improve the calendar life. ${ }^{13-16}$ FEC has largely been used in silicon-based anode materials to improve capacity retention, but has also been investigated with graphite anodes. ${ }^{15,17}$ However, there have been limited direct comparisons of the effects from FEC and VC on graphite electrodes especially related to differences in the structure of the anode SEI.

The investigations of the components and morphology changes on graphite anode surfaces upon incorporation of small quantities of additives in a standard electrolyte $1.2 \mathrm{M} \mathrm{LiPF}_{6} / \mathrm{EC}: \mathrm{EMC}(3: 7 \mathrm{v} / \mathrm{v})$ is reported. The use of binder-free graphite electrodes provides the benefit of removing the binder and conductive carbon contributions for the ex-situ analysis of electrodes by XPS, NMR, TEM and FTIR. We have also utilized Hard X-ray Photoemission Spectroscopy (HAXPES) for the analysis of cycled electrodes. The ex-situ analysis provides significant insight into the structural changes to the anode SEI upon incorporation of the electrolyte additives VC or FEC.

\section{Experimental}

Preparation of binder-free graphite electrodes and coin cell fabrication.- Binder free (BF) graphite electrodes were prepared by the Electrophoretic Deposition (EPD) method in the same manner as was previously reported. ${ }^{18}$ The EPD bath was prepared with SFG-6 graphite particles ( $\sim 5 \mu \mathrm{m}$, TIMCAL) dissolved in acetonitrile with an additional $0.1 \%$ v/v trimethylamine (anhydrous, Fisher, Co). This method results in the preparation of electrodes without polymer binders (PVDF) or conductive carbon. The electrodes are composed exclusively of SFG 6 graphite particles with a theoretical capacity of $\sim 372 \mathrm{mAh} / \mathrm{g}$. The BF-graphite electrodes were vacuum dried for $24 \mathrm{~h}$ at $120^{\circ} \mathrm{C}$, and then coin cells (CR2032) were fabricated with BF-graphite electrodes, a polypropylene separator, and lithium foil in a high purity Ar-filled glove box. The electrolytes are 1.2 $\mathrm{M} \mathrm{LiPF}_{6} /$ EC:EMC $(3: 7 \mathrm{v} / \mathrm{v})$ as the standard with $3 \%$ wt FEC or VC as additives and were obtained from a commercial supplier. Each coin cell contains $\sim 30 \mu \mathrm{L}$ of electrolyte.

Special coin cells were also assembled containing binder-free graphite electrodes with copper TEM grids. Graphite particles were removed from the center of the BF graphite electrodes to allow placement of the copper TEM grid. During cell construction some of the particles shifted from the BF graphite electrode and adhered to the copper TEM grid. Cell assembly was conducted in an Ar-atmosphere glove box $\left(<1 \mathrm{ppm}_{2} \mathrm{O}\right)$.

Electrochemical cycling. - Coin cells at $25^{\circ} \mathrm{C}$ were subjected to constant-current charge and discharge between $2.0 \mathrm{~V} \mathrm{vs.} \mathrm{Li}^{2} / \mathrm{Li}^{+}$and $0.05 \mathrm{~V}$ vs. $\mathrm{Li} / \mathrm{Li}^{+}$on a battery cycler with a current density of $\sim 50$ $\mu \mathrm{A} / \mathrm{cm}^{2}$, which is approximately a $\mathrm{C} / 20$ rate. The cells were stopped after the first lithiation and delithiation. Cyclic voltammetry was conducted in two-electrode (BF-graphite/Li) CR2032 coin cells with a potentiostat at $20^{\circ} \mathrm{C}$. The scan rate was $0.05 \mathrm{mV} / \mathrm{s}$ from 0.05 to $2 \mathrm{~V}$ vs. $\mathrm{Li} / \mathrm{Li}^{+}$. All ex-situ analysis was conducted on electrodes in the delithiated state. 
cells and rinsed with anhydrous dimethyl carbonate (DMC, Acros) to remove residual electrolyte and dried overnight in a vacuum. The TEM grids were quickly transferred into the TEM. Imaging was conducted using a commercial TEM at $160 \mathrm{kV}$. Size analysis was performed using commercial software. Energy-dispersive X-ray spectroscopy (EDX) was used to detect the elemental composition at various points in the SEI as well as on the anode; three spots from the edge to the center of particles were examined by EDX during imaging. The diameter of the beam was $5 \mathrm{~nm}$ and low-dose imaging was employed to minimize the electron beam-induced changes to the organic components of the SEI layers.

$X P S, I R$ and NMR sample preparation.- X-ray photoelectron spectroscopic (XPS) analysis of BF-graphite electrodes cycled with different electrolytes was conducted with a commercial system using an $\mathrm{Al} \mathrm{K} \alpha$ radiation source $(\mathrm{hv}=1486 \mathrm{eV})$ under ultrahigh vacuum $\left(10^{-8} \mathrm{mbar}\right)$. The samples were rapidly transferred to the XPS chamber with minimal atmospheric exposure ( $<30$ seconds), as previously described. ${ }^{18}$ The binding energies of all elements were referenced to the $\mathrm{C}-\mathrm{H}$ bonding energy at $285 \mathrm{eV}$. The spectra were analyzed and fitted with commercial software. Line syntheses of elemental spectra were conducted using Gaussian-Lorentzian (70:30) curve fitting. Elemental concentrations were calculated based on the equation: $\mathrm{Cx}=\left(\mathrm{I}_{\mathrm{x}} / \mathrm{S}_{\mathrm{x}}\right) /\left(\sum \mathrm{I}_{\mathrm{i}} / \mathrm{S}_{\mathrm{i}}\right)$, where $\mathrm{I}_{\mathrm{x}}$ is the intensity of the relative element, and $S_{i}$ is the sensitivity number. ${ }^{19}$ IR was measured by a commercial spectrometer with a Ge crystal and ATR accessory. Samples were under Ar-purge protection during the measurements. The samples were rapidly transferred to the IR spectrometer with minimal atmospheric exposure ( $<30$ seconds), as previously described. ${ }^{18}$ All NMR samples were prepared via extraction from cycled BF-graphite electrodes by $\mathrm{D}_{2} \mathrm{O}$ in an Ar-filled glove box. Before extraction, $\mathrm{BF}$-graphite electrodes were rinsed with anhydrous DMC to remove residual electrolyte and were then dried overnight under vacuum. Multinuclear NMR analyses were conducted on a $300 \mathrm{MHz}$ NMR spectrometer.

Hard X-ray photoelectron spectroscopy (HAXPES). - The HAXPES measurements were carried out at the NIST beamiline X24A at the National Synchrotron Light Source at Brookhaven National Laboratory. The beamline contains a double $\mathrm{Si}(111)$ crystal monochromator with a photon energy range of $\sim 2.1-6.0 \mathrm{keV}$. The electron energy analyzer is a hemispherical analyzer, which was operated in transmission mode at a pass energy of $500 \mathrm{eV}$, yielding an overall energy resolution of $0.45 \mathrm{eV}$ at $2200 \mathrm{eV}$ and $0.55 \mathrm{eV}$ at $4000 \mathrm{eV}$. Photoemitted $2 \mathrm{p}$ electrons from an $\mathrm{Ag}$ foil were used to calibrate the photon energy. The samples were positioned near grazing incidence with respect to the photon beam and near normal to the analyzer axis.

The electrodes were rinsed in an argon glove box, attached to a sample holder and sealed in Ar for transportation to Brookhaven National Lab. The sample bar containing all samples was then transferred to the sample chamber manipulator at beamline X24A with minimal exposure to atmosphere ( $<30 \mathrm{sec}$.). The HAXPES measurements consist of measurements of a series of core levels at incident photon energies of $2200 \mathrm{eV}$ and $4000 \mathrm{eV}$. The measured core levels are P $2 \mathrm{p}, \mathrm{C} 1 \mathrm{~s}, \mathrm{O} 1 \mathrm{~s}$, and F 1s. For each spectrum a Shirley-type background was subtracted then the core levels were fit by Voigt functions. The peak energies were referenced to the $C 1$ s pure graphite energy $(284.5 \mathrm{eV})$. All spectra for each single core level and photon energy were also normalized to the background and offset for display and comparison purposes.

\section{Results and Discussion}

Electrochemical cycling performance.- The voltage vs. capacity plots for BF-graphite cells are displayed in Figure 1. During the first lithiation and delithiation cycle, additional potential plateaus are observed upon incorporation of additives due to the reduction of the additive. The cell cycled with the standard electrolyte [1.2 $\mathrm{M} \mathrm{LiPF}_{6} /$ $\mathrm{EC}: \operatorname{EMC}(3: 7 \mathrm{v} / \mathrm{v})]$ has a shoulder at $0.6 \mathrm{~V} \mathrm{vs} . \mathrm{Li} / \mathrm{Li}^{+}$due to reduction
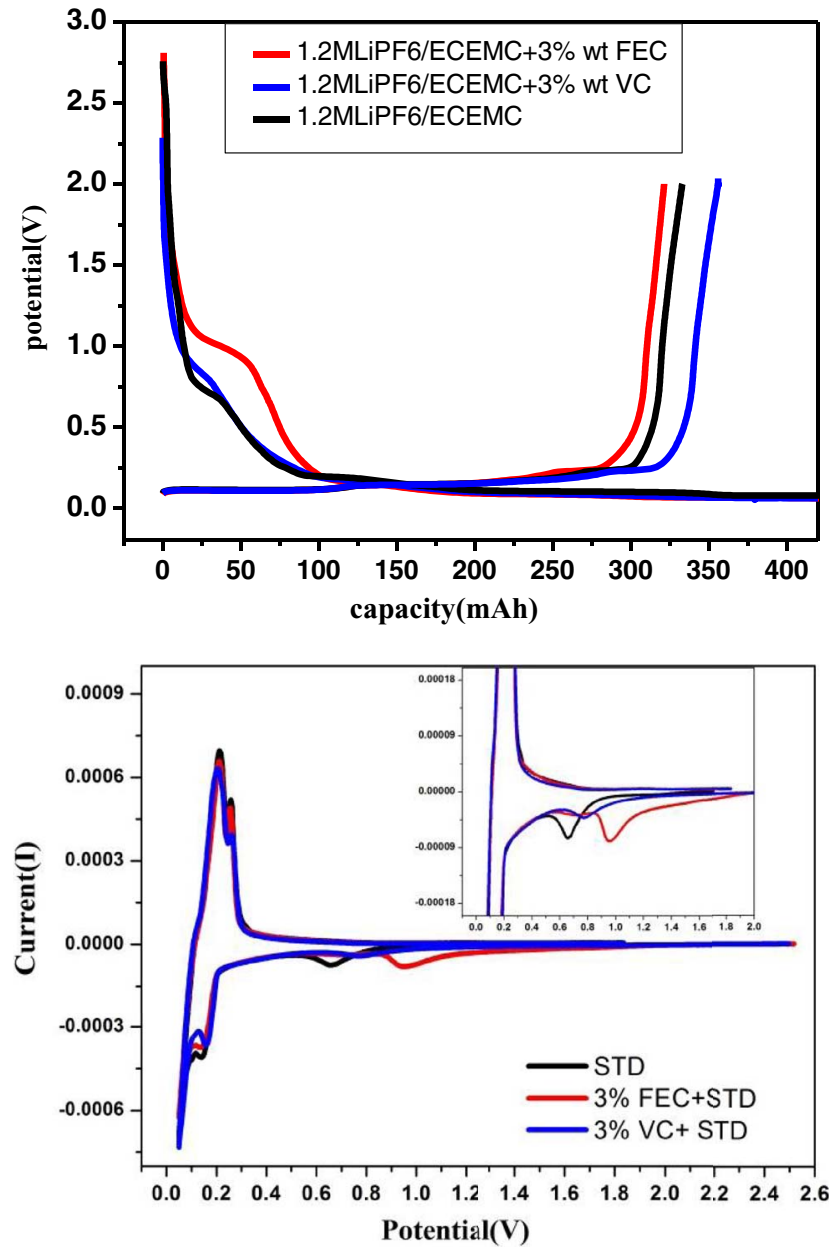

Figure 1. (Top) potential vs. capacity curves for BF-graphite/Li cells with 1.2 $\mathrm{M} \mathrm{LiPF}_{6} / \mathrm{EC}:$ EMC 3:7 v/v (STD), STD with $3 \mathrm{wt} \% \mathrm{VC}$ and STD with $3 \mathrm{wt} \%$ FEC. (bottom) cyclic voltammetry, scan rate of $0.5 \mathrm{mV} / \mathrm{s}$, for the three different electrolytes with in BF-graphite/Li coin cells.

of the electrolyte to generate an SEI resulting in a first cycle efficiency of $76 \%$. Upon incorporation of electrolyte containing $3 \% \mathrm{VC}$ the first cycle efficiency is increased to $85 \%$ and the potential plateau at $0.6 \mathrm{~V}$ vs. $\mathrm{Li} / \mathrm{Li}^{+}$is shortened. However, the cells cycled with electrolyte containing 3\% FEC displayed a lower efficiency (74\%) during the first cycle and a new large plateau is observed at $1.0 \mathrm{~V} \mathrm{vs.} \mathrm{Li} / \mathrm{Li}^{+}$ due to reduction of the FEC. ${ }^{20}$ The changes in the first cycle charging profiles and efficiencies are related to changes of the surface reactions in the presence of the additives.

Cyclic voltammetry has also been conducted on graphite/Li coin cells with all three electrolytes. The current peaks observed by $\mathrm{CV}$ occur at similar potentials to the shoulders in the constant current charging. The standard electrolyte contains a small irreversible peak at $\sim 0.7 \mathrm{~V}$ vs. $\mathrm{Li} / \mathrm{Li}^{+}$due to $\mathrm{SEI}$ formation from the EC-based electrolyte. ${ }^{21}$ The electrolyte containing FEC has a peak at $\sim 1.0 \mathrm{~V}$ vs. $\mathrm{Li} / \mathrm{Li}^{+}$with greater intensity while the electrolyte with added $\mathrm{VC}$ has a weaker intensity peak at $0.8 \mathrm{~V}$ vs. $\mathrm{Li} / \mathrm{Li}^{+}$. The reduction peaks for electrolytes containing additives are observed at higher potentials than the standard electrolyte which is consistent with sacrificial reduction of the additives. In addition, the additives suppress the peak characteristic of EC reduction at $\sim 0.7 \mathrm{~V}$ vs. $\mathrm{Li} / \mathrm{Li}^{+}$. In order to better understand how the additives change the surface reactions, ex-situ analysis has been conducted on the cells cycled with and without additives. 


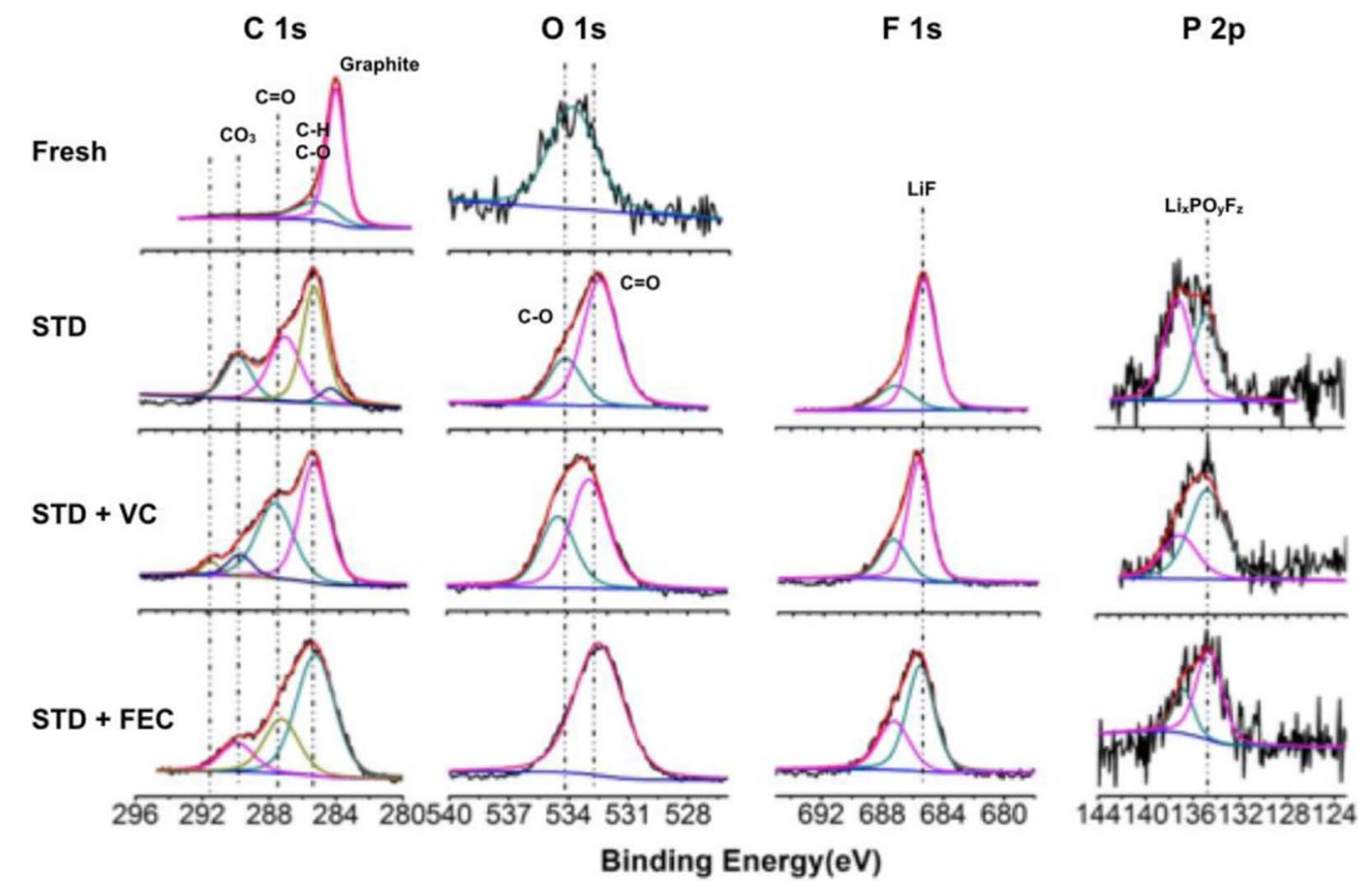

Figure 2. C 1s, O 1s, F 1s, and P 2p XPS core spectra of BF-graphite electrodes after the first cycle with $1.2 \mathrm{M} \mathrm{LiPF} / \mathrm{EC}_{\mathrm{EMC}}(30: 70 \mathrm{v} / \mathrm{v})$ as the standard electrolyte (STD), STD with 3\% FEC and STD with 3\% VC.

$X$-ray photoelectron spectroscopy.- The surfaces of the BFgraphite electrodes after cycling with electrolytes with and without additives were investigated with X-ray photoelectron spectroscopy (XPS). Element spectra and elemental concentrations are presented in Figure 2 and Table I, respectively. The $\mathrm{C}$ 1s spectrum of the fresh uncycled $\mathrm{BF}$ graphite electrode is dominated by the $\mathrm{C} 1 \mathrm{~s}$ peak characteristic of graphite $(284.5 \mathrm{eV})$. A weak peak is observed in the $\mathrm{O} 1 \mathrm{~s}$ spectrum centered at $534 \mathrm{eV}$ suggesting the presence of surface oxidation of the graphite, as typically observed. After cycling with the standard electrolyte significant new peaks characteristic of $\mathrm{C}-\mathrm{H}$, $\mathrm{C}-\mathrm{O}$, and $\mathrm{CO}_{3}$ containing species are observed at 285, 286.5, and $290 \mathrm{eV}$. Related peaks are observed in the $\mathrm{O} 1 \mathrm{~s}$ spectrum at $534 \mathrm{eV}$ and $532.5 \mathrm{eV}$ consistent with the presence of $\mathrm{C}-\mathrm{O}$ and $\mathrm{C}=\mathrm{O}$ containing species. New peaks are also observed in the $\mathrm{F} 1 \mathrm{~s}$ spectrum at $685 \mathrm{eV}$ characteristic of $\mathrm{LiF}$ and a second low intensity peak resulting from $\mathrm{LiPF}_{6} / \mathrm{Li}_{\mathrm{x}} \mathrm{PF}_{\mathrm{y}} \mathrm{O}_{\mathrm{z}}$ is observed at $\sim 688 \mathrm{eV}$. The related peaks for both $\mathrm{LiPF}_{6}$ and $\mathrm{Li}_{\mathrm{x}} \mathrm{PF}_{\mathrm{y}} \mathrm{O}_{\mathrm{z}}$ are observed in the $\mathrm{P} 2 \mathrm{p}$ spectrum at $138 \mathrm{eV}$ and $135 \mathrm{eV}$, respectively. The new peaks are accompanied by changes in the elemental concentrations (Table I). Upon cycling with the standard electrolyte, a decrease in the concentration of carbon is observed while the concentrations of $\mathrm{O}, \mathrm{F}$, and $\mathrm{P}$ are all increased. The changes to the anode surface are consistent with the deposition of electrolyte reduction products including lithium alkyl carbonates and $\mathrm{LiF}$ covering the anode surface, as previously reported. ${ }^{22}$

The XPS spectra of the BF graphite electrodes cycled with the electrolyte containing VC are also changed upon cycling (Figure 2). The intensity of the graphite peak is decreased while a significant

Table I. C 1s, O 1s, F 1s, and P 2p relative concentrations on the surface of BF-anodes cycled with three different electrolytes from the XPS results.

\begin{tabular}{lcccc} 
Elements & $\% \mathrm{C}$ & $\% \mathrm{O}$ & $\% \mathrm{~F}$ & $\% \mathrm{P}$ \\
\hline Fresh & 95 & 5 & & \\
STD & 40 & 30 & 27 & 3 \\
STD+3\%VC & 47 & 32 & 19 & 2 \\
STD $+3 \%$ FEC & 44 & 30 & 25 & 1
\end{tabular}

increase in the $\mathrm{C}-\mathrm{O}$ peak intensity is observed along with a smaller increase in the $\mathrm{CO}_{3}$ peak than observed for the standard electrolyte. An additional small shoulder is observed at $291 \mathrm{eV}$ characteristic of poly(VC). ${ }^{23,24}$ The $\mathrm{O} 1 \mathrm{~s}, \mathrm{~F} 1 \mathrm{~s}$ and $\mathrm{P} 2 \mathrm{p}$ spectra are similar to the spectra of the electrodes cycled with the standard electrolyte except that the $\mathrm{O} 1 \mathrm{~s}$ spectrum has a high energy shoulder at $534 \mathrm{eV}$ characteristic of poly(VC). ${ }^{23}$ The concentration of $\mathrm{C}$ is decreased, while the concentrations of $\mathrm{O}, \mathrm{F}$ and $\mathrm{P}$ are increased, although the decrease in the concentration of $\mathrm{C}$ and increase in the concentration of $\mathrm{F}$ are less that what was observed for the standard electrolyte (Table I). The XPS spectra are consistent with the presence of lithium alkyl carbonates, poly $(\mathrm{VC}), \mathrm{LiF}$, and low concentrations of $\mathrm{Li}_{\mathrm{x}} \mathrm{PF}_{\mathrm{y}} \mathrm{O}_{\mathrm{z}}$ on the surface of the $\mathrm{BF}$ graphite.

The XPS spectra of the BF-graphite electrode cycled with the electrolyte containing FEC are also changed upon cycling (Figure 2). New peaks characteristic of $\mathrm{CO}_{3}$ and $\mathrm{C}-\mathrm{O}$ are increased in the $\mathrm{C} 1 \mathrm{~s}$ spectrum while the peak associated with graphite is decreased. In addition, a small shoulder is observed at $291 \mathrm{eV}$ consistent with the presence of poly(FEC), ${ }^{25}$ but this peak has significantly weaker intensity than observed with added VC. The O 1s, F 1s, and P 2p spectra are very similar to that observed for the standard electrolyte. The XPS spectra are consistent with the presence of lithium alkyl carbonates, $\mathrm{LiF}$, and low concentrations of poly $(\mathrm{FEC})$ and $\mathrm{Li}_{\mathrm{x}} \mathrm{PF}_{\mathrm{y}} \mathrm{O}_{\mathrm{z}}$.

Hard X-ray photoelectron spectroscopy (HAXPES).- The C 1s, $\mathrm{O} 1 \mathrm{~s}$, and $\mathrm{F} 1 \mathrm{~s}$ core level HAXPES spectra of the cycled BF-graphite anode taken with photon energies of $1487 \mathrm{eV}$ (lab XPS), $2200 \mathrm{eV}$, and $4000 \mathrm{eV}$ are provided in Figures 3-5. The higher photon energies results in a greater depth of penetration and can provide depth dependent information of the composition of the SEI. ${ }^{26,27}$ In general, all spectra taken at photon energies of $2200 \mathrm{eV}$ and $4000 \mathrm{eV}$ are quite similar in peak energies and relative intensities. In addition, they are very similar to the XPS C 1s, O 1s, and F 1s spectra. These similarities indicate that the SEI after 1 cycle is fairly homogeneous as a function of depth for all electrolyte combinations studied in this investigation.

The HAXPES C 1s spectra, like those for XPS, revealed peaks associated with $\mathrm{C}-\mathrm{H}, \mathrm{C}-\mathrm{O}$, and $\mathrm{CO}_{3}$ species for all electrolytes (Figure 3). In the HAXPES C 1s spectra of the electrode cycled with 

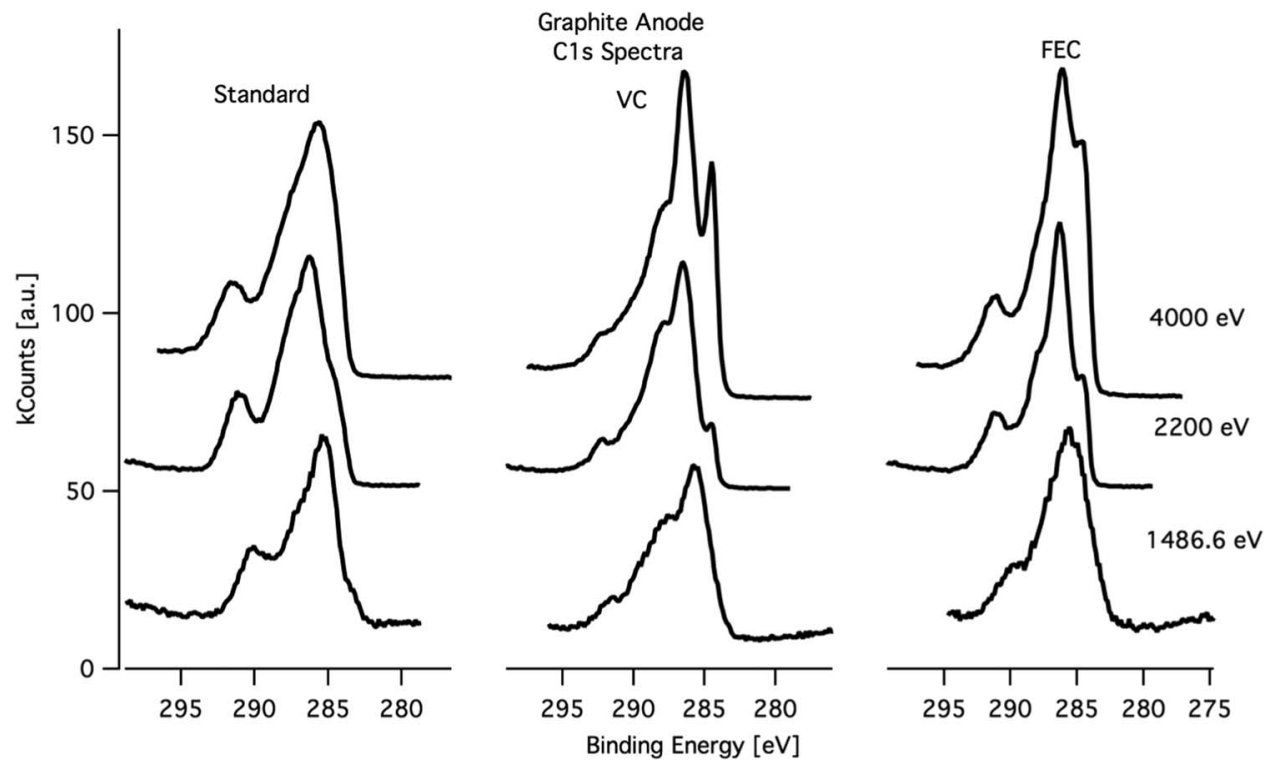

Figure 3. The $\mathrm{C} 1 \mathrm{~s}$ region of XPS (1486.6 eV - lab source) and HAXPES spectra (at $2200 \mathrm{eV}$ and $4000 \mathrm{eV}$ ) for 1 cycle graphite anodes for three electrolytes.

electrolyte containing VC, a peak/shoulder is observed at $\sim 292.5 \mathrm{eV}$ which is assigned to poly(VC). ${ }^{23}$ The only significant difference between the C 1s HAXPES and C 1s XPS spectra is the observation of distinct graphite peaks for the BF-graphite anode cycled with electrolyte containing added FEC or VC, but not for the standard electrolyte. The intensity of the graphite peaks correlate with the photon energies. No graphite peak is observed with a photon energy of $1487 \mathrm{eV}$ while graphite peaks are observed for photon energies of both $2200 \mathrm{eV}$ and $4000 \mathrm{eV}$ for BF-graphite electrodes cycled with electrolyte containing either FEC or VC. In addition, a greater relative intensity of the graphite peak is observed at $4000 \mathrm{eV}$ when compared to $2200 \mathrm{eV}$. The results suggest that the SEI generated on the graphite surface after one cycle is sufficiently thick to prevent the observation of low energy generated electrons from the underlying graphite substrate. The observation of distinct graphite peaks in higher photon energy HAXPES spectra for the electrodes cycled with electrolyte containing added FEC or VC suggests that the SEI layer is thinner upon incorporation of either FEC or VC.
The F 1s XPS and HAXPES spectra for the electrode cycled with the standard electrolyte, electrolyte with added FEC and electrolyte with added $\mathrm{VC}$ have one main peak assigned to $\mathrm{LiF}$ and a second small shoulder which is assigned to $\mathrm{LiPF}_{6} / \mathrm{Li}_{\mathrm{x}} \mathrm{PF}_{\mathrm{y}} \mathrm{O}_{\mathrm{z}}$ (Figure 4). There is no clear depth dependence of the F1s spectra suggesting that the F containing species are homogeneous throughout the SEI. The O 1s XPS and HAXPES spectra exhibit a broad peak assigned to a combination of $\mathrm{C}-\mathrm{O}, \mathrm{C}=\mathrm{O}$, and $\mathrm{CO}_{3}$ for the electrode cycled with the standard electrolyte (Figure 5). Small differences are observed for the XPS and HAXPES spectra of the BF-graphite electrodes cycled with electrolyte containing VC or FEC. The electrodes have a distinct high energy shoulder in the $\mathrm{O} 1 \mathrm{~s}$ spectra consistent with the presence of poly(VC) or poly(FEC), respectively. The intensity of the high energy shoulder is greater for the electrodes cycled with electrolyte containing VC than for the electrode cycled with electrolyte containing FEC, which is in agreement with the $\mathrm{C} 1 \mathrm{~s}$ spectra. However, there does not appear to be a significant difference for different photon energies suggesting that the composition of the SEI is homogeneous.
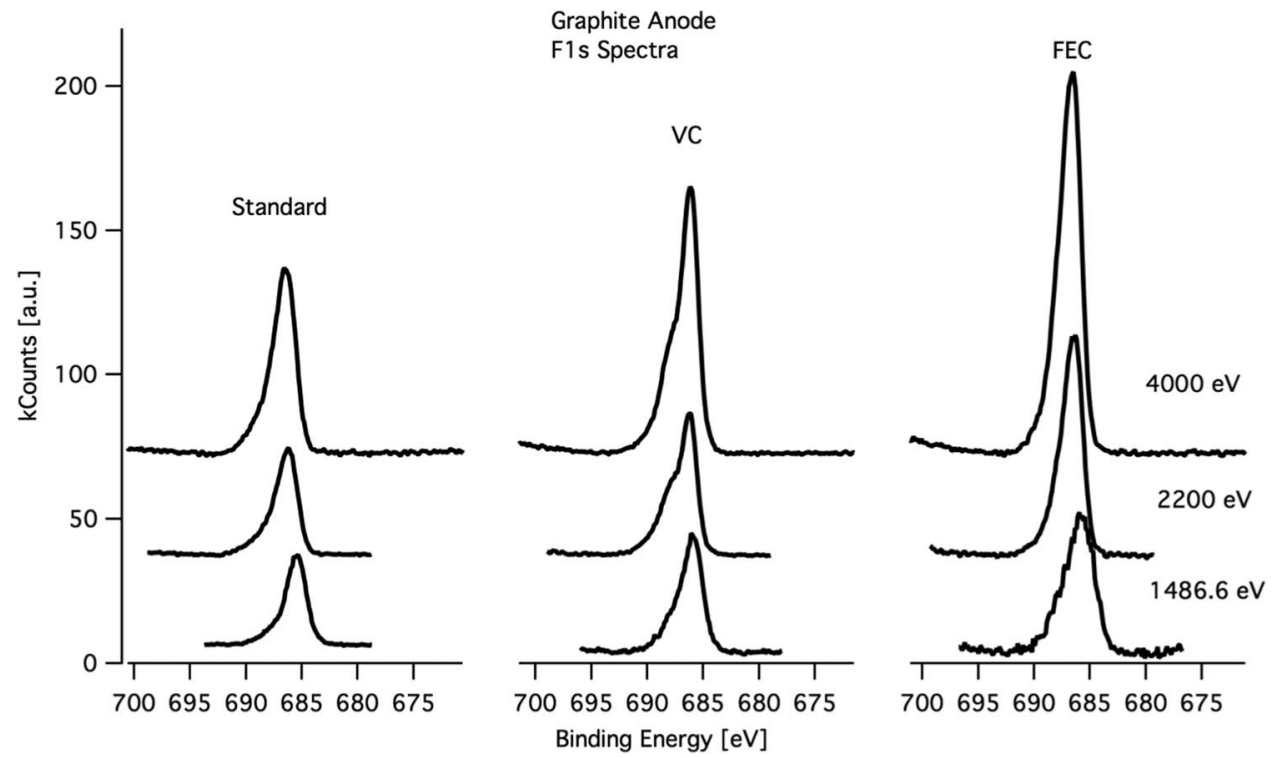

Figure 4. The F 1s region of XPS (1486.6 eV - lab source) and HAXPES spectra (at $2200 \mathrm{eV}$ and $4000 \mathrm{eV}$ ) for 1 cycle samples for three electrolytes. 

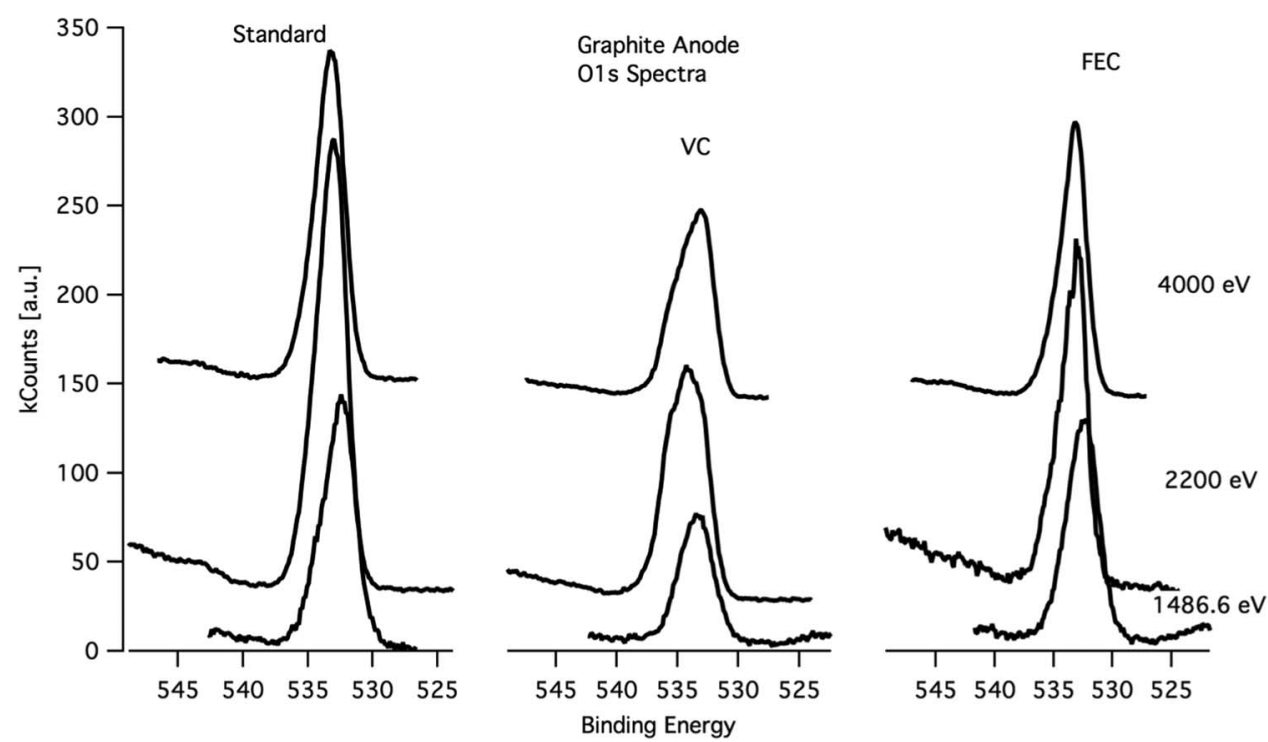

Figure 5. The O1s region of XPS (1486.6 eV - lab source) and HAXPES spectra (at $2200 \mathrm{eV}$ and $4000 \mathrm{eV}$ ) for 1 cycle samples for three electrolytes.

Infrared spectroscopy. - Spectra of the fresh graphite electrode and the electrode after one cycle with standard electrolyte, electrolyte with added FEC and electrolyte with added VC are depicted in Figure 6. The FTIR spectra of the BF-graphite electrodes cycled with the standard electrolyte contain peaks characteristic of lithium alkyl carbonates $1650,1395,1305$, and $1080 \mathrm{~cm}^{-1}$, as previously reported. ${ }^{18}$ The electrode after one cycle with FEC and VC also contain the peaks characteristic of lithium alkyl carbonates, but have additional new absorptions. The new absorptions for electrodes cy-

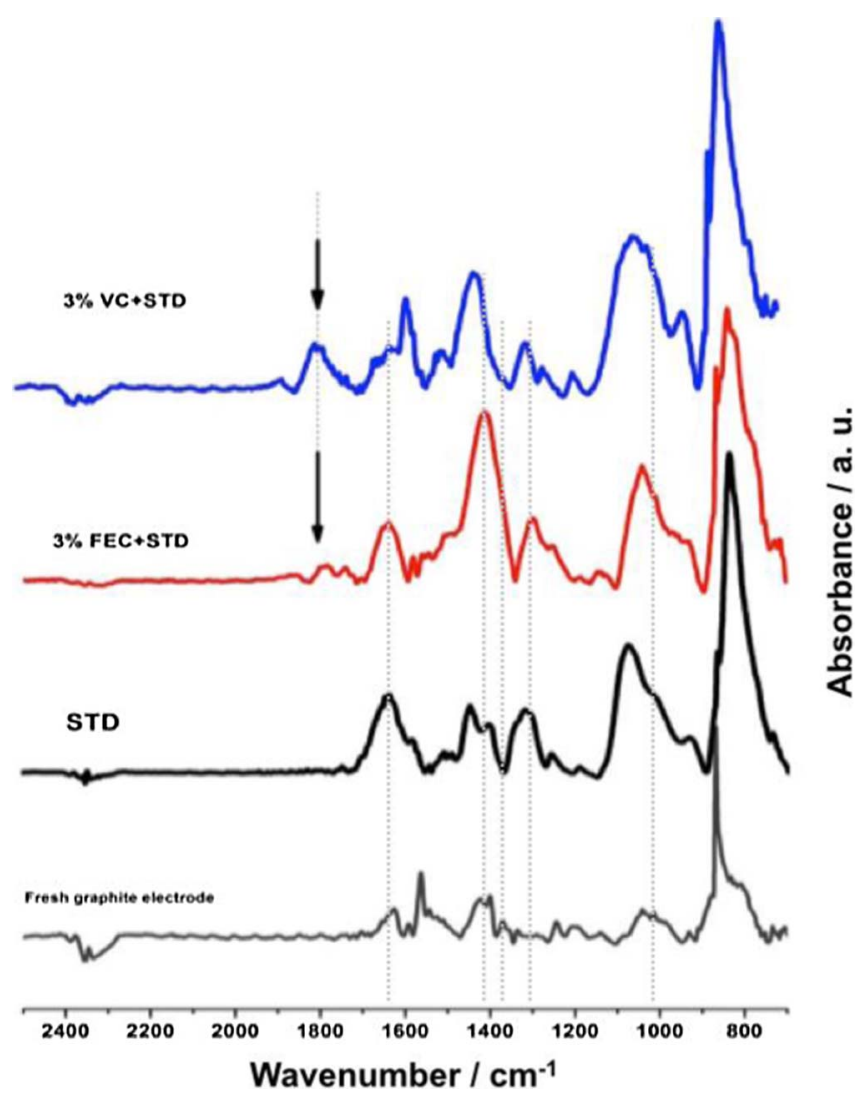

Figure 6. FTIR-ATR spectra of a fresh electrode, an electrode cycled with $3 \%$ FEC and an electrode cycled with $3 \% \mathrm{VC}+1.2 \mathrm{M} \mathrm{LiPF}_{6} / \mathrm{EC}: \mathrm{EMC}(3: 7)$. cled with electrolytes containing either FEC or VC, are observed at $1440 \mathrm{~cm}^{-1}$ characteristic of $\mathrm{Li}_{2} \mathrm{CO}_{3}$ and at $1780 \mathrm{~cm}^{-1}$ characteristic of poly(FEC) or poly(VC), respectively. ${ }^{28,29}$ The intensity of the $\mathrm{Li}_{2} \mathrm{CO}_{3}$ peak is greater for the electrode cycled with electrolyte containing FEC while the intensity of the polymer peak is greater for the electrode cycled with $\mathrm{VC}$ suggesting that more $\mathrm{Li}_{2} \mathrm{CO}_{3}$ is generated by the reduction of FEC and more polymer is generated by the reduction of VC.

Transmission electron spectroscopy.-BF-graphite electrodes were analyzed by TEM after cycling with all of the electrolytes investigated revealing the presence of an SEI. The BF-graphite anode cycled with the standard electrolyte has a smooth surface film, which is $10-40 \mathrm{~nm}$ thick (Figure 7). The elemental concentration in the center of the particle (point 1, Figure 7) is predominantly carbon as expected for the bulk electrode material. However, at the edge of the particle, which is dominated by the SEI, the concentrations of $\mathrm{O}$ and $\mathrm{F}$ are much higher, consistent with the presence of an SEI composed of lithium alkyl carbonates and $\mathrm{LiF}^{18}$

The TEM images of the BF-graphite anode cycled with electrolyte containing added VC reveal a smooth but thinner SEI (10-20 nm) (Figure 7). The concentration of $\mathrm{O}$ is higher than the concentration of $\mathrm{F}$ consistent with an SEI which has higher concentrations of $\mathrm{O}$ containing species such as $\mathrm{Li}_{2} \mathrm{CO}_{3}$ and poly(VC) and lower concentrations of $\mathrm{LiF}$. The observation of a thinner SEI with added $\mathrm{VC}$ is consistent with the HAXPES $\mathrm{C}$ 1s results.

BF-graphite anodes extracted from cells cycled with electrolyte containing added FEC were also analyzed by TEM (Figure 7). The surface morphology is quite different upon incorporation of FEC. The surface film on the graphite particles is thin (10-20 nm) and grainy. The films have a higher concentration of $\mathrm{F}$ than $\mathrm{O}$, suggesting a surface film which is rich in LiF which is consistent with the XPS data discussed above and previous reports which suggest that the reduction of FEC results in the generation of $\mathrm{LiF}^{22}$

NMR multinuclear analysis of BF-graphite anodes extracted by $\mathrm{D}_{2} \mathrm{O}$.- Binder free graphite electrodes were extracted with $\mathrm{D}_{2} \mathrm{O}$ for ${ }^{1} \mathrm{H}$ and ${ }^{19} \mathrm{~F}$ NMR analysis (Figure 8). The ${ }^{1} \mathrm{H}$ NMR spectra of the $\mathrm{D}_{2} \mathrm{O}$ extract of an anode after one cycle with $\mathrm{LiPF}_{6} / \mathrm{EC}: \mathrm{EMC}$ electrolyte contain two peaks (Figure 8) at $3.51 \mathrm{ppm}$ (singlet) and $3.20 \mathrm{ppm}$ (singlet) consistent with the formation of Lithium Ethylene Dicarbonate (LEDC) and Lithium Methyl Carbonate (LMC), as previously reported. ${ }^{18}$ 


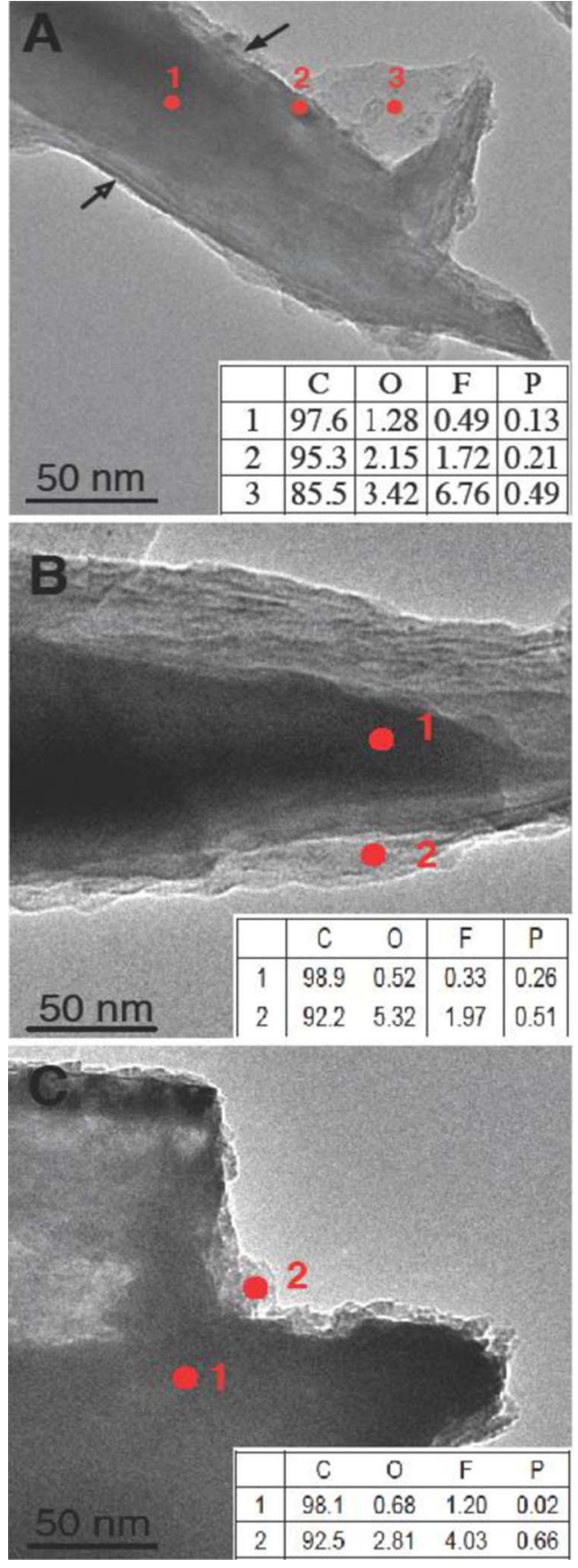

Figure 7. TEM images of graphite particles after the first cycle with (A) STD electrolyte, (B) STD with 3\%VC and (C) STD with 3\% FEC.

The ${ }^{1} \mathrm{H}$ NMR spectrum of the $\mathrm{D}_{2} \mathrm{O}$ extract of the BF-graphite anode cycled with the electrolyte containing electrolyte with added $\mathrm{VC}$ is provided in Figure 8. A single peak is observed characteristic of LEDC. However, the relative intensity of the LEDC peak is much less than observed for the electrode cycled with the standard electrolyte. This suggests that the incorporation of VC results in an inhibition of LEDC generation, as previously reported. ${ }^{30}$ No other products are observed by ${ }^{1} \mathrm{H}$ NMR spectroscopy suggesting that the reduction product of $\mathrm{VC}$, poly $(\mathrm{VC})$, is not soluble in $\mathrm{D}_{2} \mathrm{O}$.

The ${ }^{1} \mathrm{H}$ NMR spectrum of the BF-graphite electrode cycled with electrolyte containing added FEC is provided in Figure 8. Similar results are observed to the electrode cycled with the electrolyte containing VC. A single peak characteristic of LEDC is observed and the relative intensity is much lower suggesting that reduction of FEC also
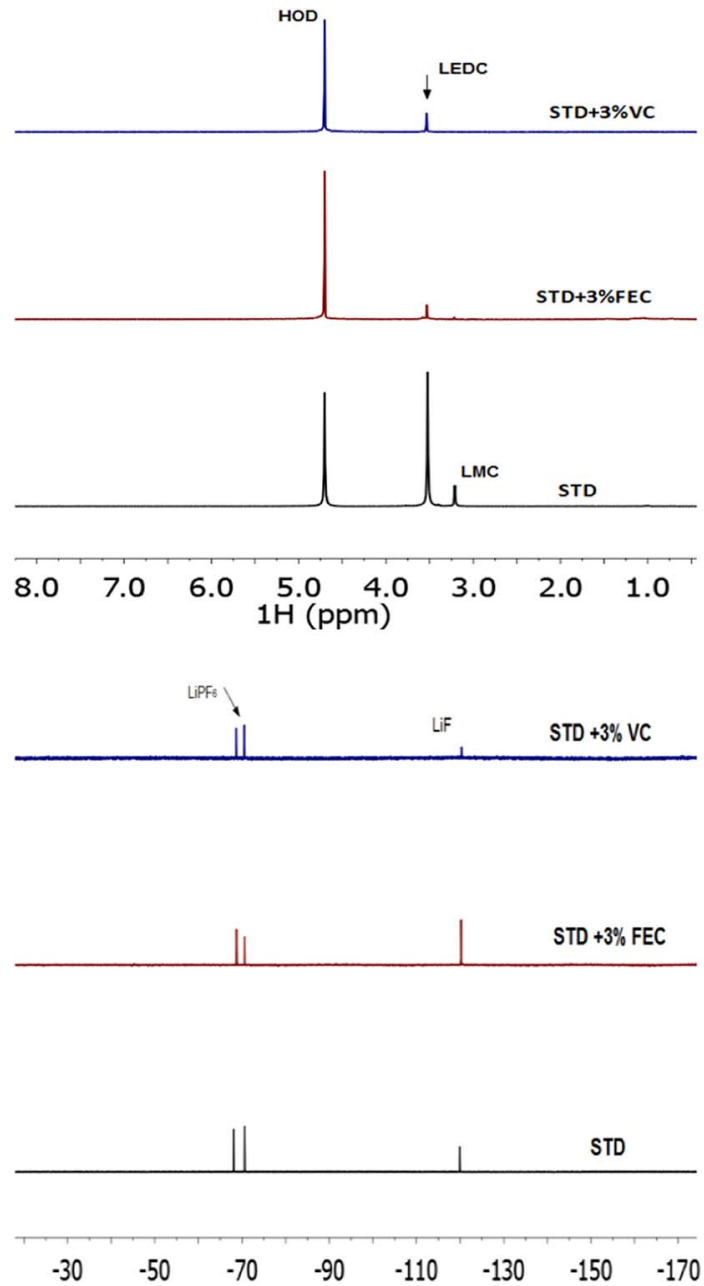

Figure 8. (Top) ${ }^{1} \mathrm{H}$ NMR spectra of the $\mathrm{D}_{2} \mathrm{O}$ extracts of BF-graphite electrodes cycled with three different electrolytes, $1.2 \mathrm{M} \mathrm{LiPF}_{6} / \mathrm{EC}$ :EMC with $3 \%$ $\mathrm{VC}, 1.2 \mathrm{M} \mathrm{LiPF}_{6} / \mathrm{EC}: \mathrm{EMC}$ with $3 \% \mathrm{FEC}$, and $1.2 \mathrm{M} \mathrm{LiPF}_{6} / \mathrm{EC}: \mathrm{EMC}$ (STD). (Bottom). ${ }^{19} \mathrm{~F}$ NMR spectra of the $\mathrm{D}_{2} \mathrm{O}$ extracts of BF-graphite electrodes cycled three different electrolytes.

inhibits EC and EMC reduction to generate LEDC and LMC, respectively. No other products were observed by ${ }^{1} \mathrm{H}$ NMR spectroscopy consistent with insolubility of poly(FEC) in $\mathrm{D}_{2} \mathrm{O}$.

Analysis of the $\mathrm{D}_{2} \mathrm{O}$ extract with ${ }^{19} \mathrm{~F}$ NMR spectroscopy in Figure 8 reveals the presence of a doublet at $-72.2 \mathrm{ppm}$, characteristic of $\mathrm{LiPF}_{6}$ and a singlet at $-123.0 \mathrm{ppm}$ characteristic of $\mathrm{LiF}$ for all electrolytes investigated. Surprisingly, while the rate of decomposition of $\mathrm{LiPF}_{6}$ in carbonate solvents is accelerated with added protic solvents, the ratio of $\mathrm{LiPF}_{6}$ to $\mathrm{LiF}$ does not change upon storage in $\mathrm{D}_{2} \mathrm{O}$ in the absence of $\mathrm{O}_{2}$ for a week at $25^{\circ} \mathrm{C}$, consistent with stability of $\mathrm{LiPF}_{6}$ in $\mathrm{D}_{2} \mathrm{O}^{31}$ Interestingly, the intensity of the $\mathrm{LiF}$ resonance, relative to the residual $\mathrm{LiPF}_{6}$, is greatest for the electrolyte with added FEC, followed by the standard electrolyte and is lowest for the electrolyte with added VC. This is consistent with the XPS and TEM results, which suggest that $\mathrm{VC}$ inhibits $\mathrm{LiF}$ formation on the anode surface and that reduction of FEC results in the formation of $\mathrm{LiF}$.

\section{Conclusions}

The structure of the initial solid electrolyte interface (SEI) on BF-graphite anodes as a function of electrolyte additives has been investigated via a combination of XPS, HAXPES, IR-ATR, TEM, and $\mathrm{D}_{2} \mathrm{O}$ extractions of the electrodes. The results from the different analytical methods are in general agreement. The SEI generated in 
the presence of the standard electrolyte is $20-40 \mathrm{~nm}$ thick and is predominantly composed of a combination of lithium alkyl carbonates and $\mathrm{LiF}$.

Incorporation of $3 \% \mathrm{VC}$ into the standard electrolyte results in a modification of the anode SEI. The SEI still contains lithium alkyl carbonates and $\mathrm{LiF}$, but the concentration of lithium alkyl carbonates and $\mathrm{LiF}$ are reduced and the SEI is thinner (10-20 nm) and contains both $\mathrm{Li}_{2} \mathrm{CO}_{3}$ and poly(VC). This suggests that incorporation of $\mathrm{VC}$ inhibits the reduction of EC to generate $\mathrm{LEDC}$ and $\mathrm{LiPF}_{6}$ to generate LiF.

For the electrolyte containing FEC, there is also a decrease in the concentration of lithium alkyl carbonates, but the concentration of $\mathrm{LiF}$ is similar. This is consistent with a decrease in the reduction of EC. Since the reduction of FEC has been reported to generate $\mathrm{LiF}$, it is also consistent with a decrease in the reduction of $\mathrm{LiPF}_{6}$. The SEI also contains $\mathrm{Li}_{2} \mathrm{CO}_{3}$ and a polymeric species (poly(FEC)), although the concentration of poly(FEC) in the SEI is lower than the concentration of poly(VC) in the SEI for the VC containing electrolyte. The anode SEI is thinner $(10-20 \mathrm{~nm})$ than that observed for the standard electrolyte, but has a grainier structure that may result from the higher concentration of inorganic species in the $\mathrm{SEI}\left(\mathrm{LiF}\right.$ and $\left.\mathrm{Li}_{2} \mathrm{CO}_{3}\right)$.

\section{Acknowledgment}

The authors gratefully acknowledge funding from Department of Energy Office of Basic Energy Sciences EPSCoR Implementation award (DE-SC0007074).

\section{References}

1. V. Etacheri, R. Marom, R. Elazari, G. Salitra, and D. Aurbach, Energy \& Environmental Science, 4, 3243 (2011)

2. M. M. Thackeray, C. Wolverton, and E. D. Isaacs, Energy \& Environmental Science, 5, 7854 (2012).

3. B. Scrosati, J. Hassoun, and Y.-K. Sun, Energy \& Environmental Science, 4, 3287 (2011).

4. K. Xu, Chemical reviews, 114, 11503 (2014).

5. K. Xu, Chemical reviews, 104, 4303 (2004).

6. S. Zhang, M. S. Ding, K. Xu, J. Allen, and T. R. Jow, Electrochemical and Solid-State Letters, 4, A206 (2001)
7. J. Vetter, P. Novák, M. R. Wagner, C. Veit, K. C. Möller, J. O. Besenhard, M. Winter, M. Wohlfahrt-Mehrens, C. Vogler, and A. Hammouche, Journal of Power Sources, 147, 269 (2005).

8. V. A. Agubra and J. W. Fergus, Journal of Power Sources, 268, 153 (2014).

9. M. N. Richard and J. R. Dahn, Journal of The Electrochemical Society, 146, 2068 (1999).

10. L. Ma, J. Xia, X. Xia, and J. R. Dahn, Journal of the Electrochemical Society, 161 A1495 (2014)

11. M. Winter, W. K. Appel, B. Evers, T. Hodal, K.-C. Möller, I. Schneider, M. Wachtler, M. R. Wagner, G. H. Wrodnigg, and J. O. Besenhard, Monatshefte fuer Chemie, 132, 473 (2001).

12. S.-K. Jeong, M. Inaba, R. Mogi, Y. Iriyama, T. Abe, and Z. Ogumi, Langmuir, 17, $8281(2001)$

13. K. Abe, H. Yoshitake, T. Kitakura, T. Hattori, H. Wang, and M. Yoshio, Electrochim. Acta, 49, 4613 (2004).

14. P. Verma, P. Maire, and P. Novák, Electrochim. Acta, 55, 6332 (2010).

15. D. Y. Wang, N. N. Sinha, J. C. Burns, C. P. Aiken, R. Petibon, and J. R. Dahn, Journal of the Electrochemical Society, 161, A467 (2014).

16. M. Broussely, P. Biensan, F. Bonhomme, P. Blanchard, S. Herreyre, K. Nechev, and R. J. Staniewicz, Journal of Power Sources, 146, 90 (2005).

17. C. Xu, F. Lindgren, B. Philippe, M. Gorgoi, F. Björefors, K. Edström, and T. Gustafsson, Chemistry of Materials, 27, 2591 (2015).

18. M. Nie, D. Chalasani, D. P. Abraham, Y. Chen, A. Bose, and B. L. Lucht, The Journal of Physical Chemistry C, 117, 1257 (2013).

19. R. Benoit, Vide-Sci. Techn. Appl., 58, 219 (2003).

20. R. McMillan, H. Slegr, Z. X. Shu, and W. Wang, Journal of Power Sources, 81-82, 20 (1999).

21. R. Imhof and P. Novák, Journal of The Electrochemical Society, 145, 1081 (1998).

22. M. Nie, D. P. Abraham, Y. Chen, A. Bose, and B. L. Lucht, The Journal of Physical Chemistry C, 117, 13403 (2013)

23. L. El Ouatani, R. Dedryvère, C. Siret, P. Biensan, S. Reynaud, P. Iratçabal, and D. Gonbeau, Journal of The Electrochemical Society, 156, A103 (2009).

24. L. Martin, H. Martinez, M. Ulldemolins, B. Pecquenard, and F. Le Cras, Solid State Ionics, 215, 36 (2012).

25. W. Zhang, F. Ghamouss, A. Darwiche, L. Monconduit, D. Lemordant, R. Dedryvère, and H. Martinez, Journal of Power Sources, 268, 645 (2014).

26. B. Philippe, R. Dedryvère, J. Allouche, F. Lindgren, M. Gorgoi, H. Rensmo, D. Gonbeau, and K. Edström, Chemistry of Materials, 24, 1107 (2012).

27. B. Philippe, R. Dedryvère, M. Gorgoi, H. Rensmo, D. Gonbeau, and K. Edström, Chemistry of Materials, 25, 394 (2013).

28. C. C. Nguyen and B. L. Lucht, Journal of the Electrochemical Society, 161, A1933 (2014).

29. V. Etacheri, O. Haik, Y. Goffer, G. A. Roberts, I. C. Stefan, R. Fasching, and D. Aurbach, Langmuir, 28, 965 (2012).

30. B. Zhang, M. Metzger, S. Solchenbach, M. Payne, S. Meini, H. A. Gasteiger, A. Garsuch, and B. L. Lucht, The Journal of Physical Chemistry C, 119, 11337 (2015).

31. C. L. Campion, W. Li, and B. L. Lucht, Journal of The Electrochemical Society, 152, A2327 (2005) 